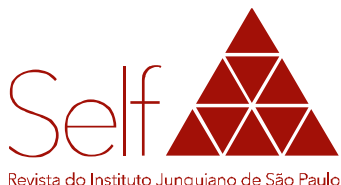

\title{
Produção científica em foco
}

\section{Scientific production in focus}

\section{Enfoque en la producción científica}

A Self, revista do Instituto Junguiano de São Paulo (IJUSP), chega em 2020 ao seu quinto ano de atividade, mantendo-se firme em seu objetivo maior: o de promover e divulgar o pensamento junguiano com critérios científicos e padrões de publicação internacionalmente reconhecidos.

Com um conteúdo de alto nível, a Self pode ser acessada gratuitamente online por qualquer pessoa, democratizando assim o conhecimento de qualidade. Todo o processo editorial é realizado dentro da plataforma digital da revista, que adota o sistema rolling pass de publicação: os artigos são publicados na medida em que são aprovados, o que traz agilidade à divulgação.

Ao longo de 2019 o volume 4 apresentou um total de 13 trabalhos, sendo: dois editoriais, oito artigos de reflexão, um estudo de caso, uma entrevista e uma resenha.

O editorial que abriu 2019 abordou o tema do congresso da Associação Junguiana do Brasil (AJB): "Emergências na sociedade contemporânea". Logo em seguida, a Self publicou o editorial sobre Brumadinho, um texto bastante oportuno, escrito por Dulce Helena Rizzardo Briza.

Os artigos de reflexão trouxeram importantes questionamentos sobre 0 manejo clínico. O texto de Alberto Lima Filho enfocou as tessituras da conduta das pessoas e seus desdobramentos psicológicos; Irene Gaeta nos apresentou um estudo sobre a influência do animus materno na vida do filho; a contra-transferência foi tema do artigo de Marlon Reikdal, que nos remeteu ao símbolo apolíneo; a religiosidade como função psíquica pela perspectiva de C. G. Jung foi objeto de estudo de Punita Miranda, pesquisadora brasileira radicada na Europa; Adriane Bacarin tratou do resgate do feminino em Maria de Magdala e a função transcendente; a beleza e sua dimensão multifacetada foi o tema apresentado por Maria Elci Spaccaquerche; Leão Serva discutiu a fotografia de cenas de guerra como fator desencadeante de estresse pós-traumático; e, por fim, Marieta Messina 
ofereceu um estudo sobre o processo de individuação feminino no conto de fada "Pele de asno".

De autoria de Clara Ferraro de Sá, o estudo de caso demonstrou como as técnicas expressivas podem ser usadas como recurso terapêutico.

Realizada pelo Núcleo de Arte e Psicologia Analítica (NAPA) do IJUSP, a entrevista com $O$ analista Franklin Chang permitiu que, através de suas histórias, pudéssemos nos aproximar e conhecer melhor o trabalho de Nise da Silveira.

A resenha de Priscila Tessicini sobre o filme "Coringa", nossa última publicação do ano, fez uma leitura da obra cinematográfica e levantou importantes questões relacionadas à saúde mental.

Neste começo de 2020, iniciamos o volume 5 da Self com o desejo de nos tornamos cada vez mais um veículo de comunicação científica de cuidadosa qualidade editorial, voltado para quem estuda, pesquisa ou se interessa em conhecer as diferentes visões dos que estão envolvidos com a clínica junguiana.

Esperamos assim que a Self represente um incentivo e um acolhimento para que todos aqueles que tenham a psicologia analítica como referência sintam-se entusiasmados a escrever e a publicar seus trabalhos.

Paula Serafim Daré \& Candido Pinto Vallada Instituto Junguiano de São Paulo, São Paulo/SP, Brasil 